\title{
REVIEW
}

\section{Restricted Access Molecularly Imprinted Polymers for Biological Sample Preparation}

\author{
Tássia Venga Mendes ${ }^{D}$, Mariana Azevedo Rosa ${ }^{D}$, Eduardo Costa de Figueiredo* $\triangle$ \\ Tássia Venga Mendes and Mariana Azevedo Rosa contributed equally to this work.
}

Faculdade de Ciências Farmacêuticas, Universidade Federal de Alfenas, Rua Gabriel Monteiro da Silva, 700, 37130-000, Alfenas, MG, Brazil

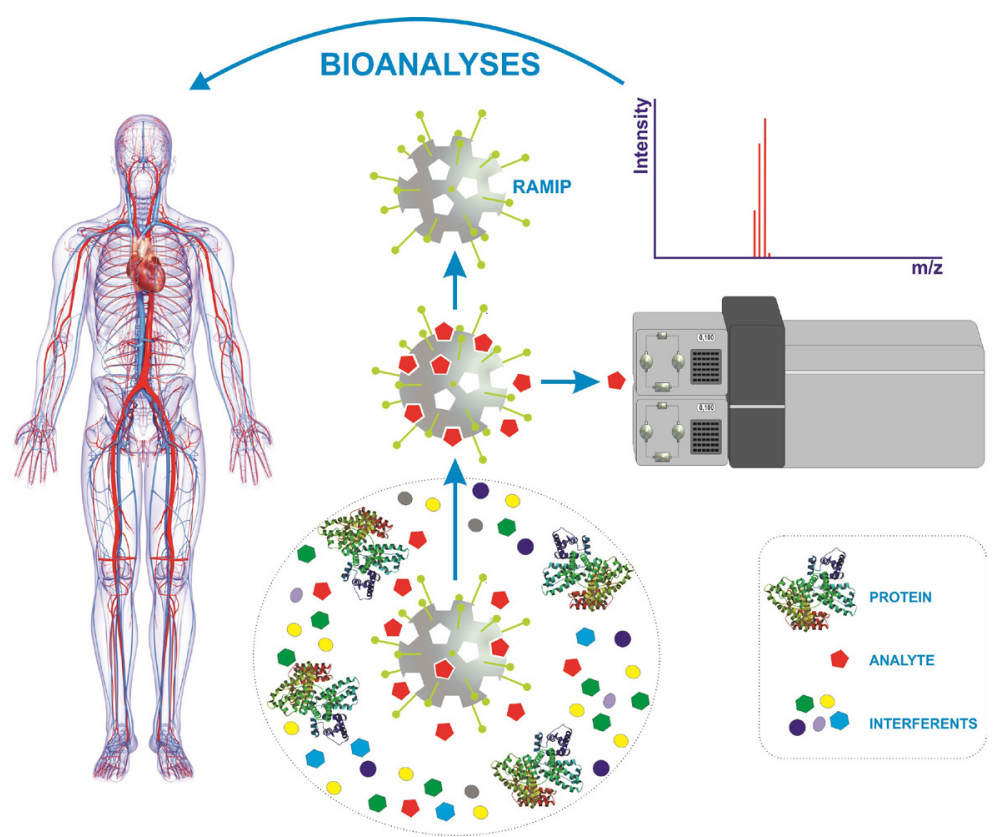

BIOLOGICAL SAMPLE PREPARATION WITH RAMIP
Restricted access molecularly imprinted polymers (RAMIPs) have been efficiently used for the extraction of small organic molecules from untreated biological matrices (e.g. blood, plasma, serum, and milk). These materials have been obtained by modifying the external surface of conventional molecularly imprinted polymers (MIPs) with hydrophilic monomer grafting, crosslinked protein capsule or a combination of both. These sorbents aggregate the selectivity of MIPs with the ability to exclude macromolecules of restricted access materials (RAMs), being widely employed in solid phase extraction techniques, beyond their use in sensors. In this review, we discuss about the design and application of RAMIPs in biological sample preparation, emphasizing the future trends and remaining challenges of this technology for bioanalyses.

Keywords: molecularly imprinted polymers, restricted access materials, restricted access molecularly imprinted polymers, sample treatment, protein exclusion

\section{INTRODUCTION}

Molecularly imprinted polymers (MIPs) are selective materials obtained by the copolymerization of functional monomers and crosslinker agents, in the presence of a template molecule [1,2]. The selective recognition ability to the template (in terms of size, shape, and chemical functionality [3]) is the more important characteristic of MIPs. High stability, adsorption capacity, reproducibility and reusability can also

Cite: Mendes, T. V.; Rosa, M. A.; Figueiredo, E. C. Restricted Access Molecularly Imprinted Polymers for Biological Sample Preparation. Braz. J. Anal. Chem., 2022, 9 (35), pp 18-38. http://dx.doi.org/10.30744/brjac.2179-3425.RV-90-2021 
be highlighted [2]. The first reported application of MIPs in solid phase extraction (SPE) occurred in 1994 [4], and since then, MIPs become well-established materials in sample preparation.

Despite their advantages, the direct used of MIPs to prepare untreated biological samples (e.g. milk, plasma, serum, blood, among others) can be difficult due to the presence of proteins, polypeptides, and lipids, that can be retained on the polymer surface, causing sensitivity and selectivity problems [5]. To circumvent this situation, additional steps of sample preparation have been performed before the molecularly imprinted solid phase extraction (MISPE), as for example, the protein precipitation. On the other hand, sample dilution, drastic $\mathrm{pH}$ changes, loss of analytes through co-precipitation, and ionic suppression in mass spectrometry are the main recurrent problems of this strategy [6].

Considering these limitations, in 1999 Haginaka et al. [7] synthesized the first restricted access molecularly imprinted polymer (RAMIP), that was a MIP with the additional capacity to exclude macromolecules. The exclusion mechanisms were based on the concepts of restricted access materials (RAMs), by the presence of physical (size pores) and/or chemical (hydrophilic external layer) diffusion barriers [8,9]. Low molecular target molecules can penetrate through these barriers, being retained by partition, ion exchange and/or adsorption process $[10,11]$, whereas the macromolecules are excluded. The protective barriers can also prevent the influence of water in the selective interactions between target molecule and RAMIP $[7,12,13]$, improving the selectivity.

Some reviews were published in the past years about the use of RAMs or MIPs in sample preparation [1,3,14-18] and/or coupled to analytical techniques [1,19-26]. Future and promising trends for both materials were highlighted $[14,17,19,21,27]$. However, none of these reviews had RAMIPs as their focus and the RAMIP term hardly was observed (no more than a citation or one topic with a summarized explanation). An exception is the review of De Faria et al. (2017) [3], in which a more complete description of RAMIPs was observed.

The present review is the first totally dedicated to the RAMIP, with an actualization of the types and synthesis methodologies, as well as with recent examples of applications. Different mechanisms of protein exclusion are deeply described. Advances, remaining gaps, advantages, disadvantages, and challenges are also discussed.

\section{RAMIPS OBTAINED BY HYDROPHILIC COMONOMERS GRAFTING}

To obtain RAMIPs by hydrophilic comonomers grafting, the comonomers are added in the reactional flask together with the MIP synthesis reagents. Therefore, a dense region of hydroxyl groups is created on the polymer surface during the polymerization step. The hydrophilic comonomers are generally added after a pre-polymerization step (functional monomer + template in porogenic solvent) to avoid possible interferences in the formation of specific imprinted binding sites. Figure 1 shows a general synthesis scheme of these materials.

The mechanism of macromolecules exclusion by the hydrophilic layer is discussed in some papers about the preparation of different RAMs $[3,10,28,29]$. The authors suggest that the access of macromolecules to the material's inner is avoided by the small pores, and the accumulation of the proteins is averted by a chemical diffusion barrier created by the hydrophilic chains. The primary thermodynamic interaction between protein and support is the hydrophobic effect [30]. Thus, generally, proteins are more adsorbed on hydrophobic surfaces than on hydrophilic ones (releases a large amount of entropy) [30,31]. Therefore, the proteins present in the matrix are eliminated and the binding sites of the RAMIPs are not obstructed. 


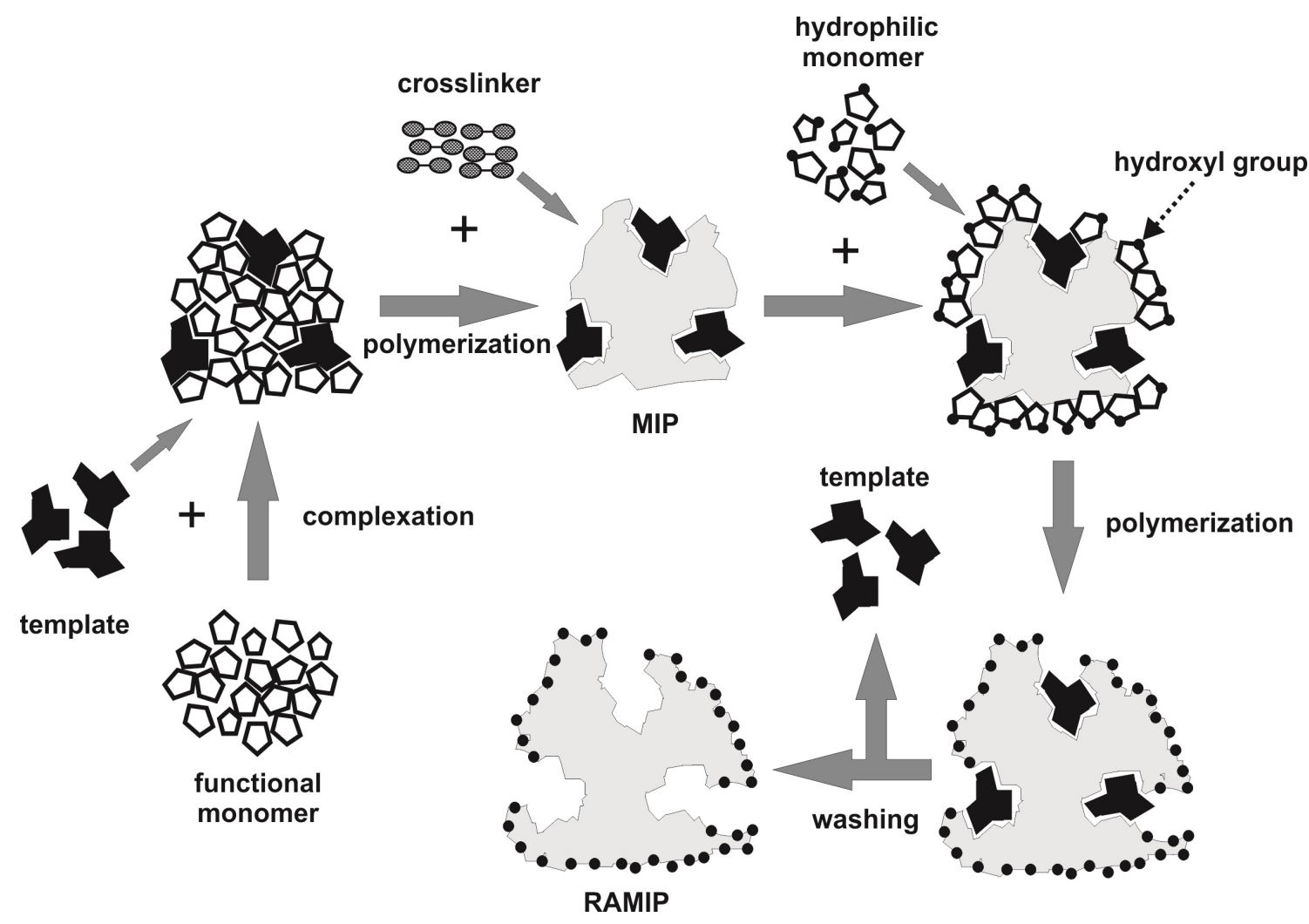

Figure 1. General synthesis scheme of the RAMIP obtained by hydrophilic comonomers grafting. (Reprinted with permission from De Faria, H. D.; Abrão, L. C. de C.; Santos, M. G.; Barbosa, A. F.; Figueiredo, E. C. Anal. Chim. Acta, 2017, 959, pp 43-65 https://doi.org/10.1016/j.aca.2016.12.047 Copyright@ (2017), Elsevier.)

Wang et al. (2011) [28] demonstrated that a silica material presented lower total pore area, lower average pore diameter, and higher protein exclusion rate after its functionalization with hydrophilic comonomers: 376.1 and $280.7 \mathrm{~m}^{2} \mathrm{~g}^{-1}, 98.9$ and $80.7 \AA$, and 5.3 and $98.2 \%$, respectively. The pore structures of the materials were analyzed by a nitrogen sorption system, and the protein exclusion test was performed using bovine serum albumin solution. These results showed that the formation of the external layer influenced the macromolecules exclusion by the synthesized material. Xu et al. (2010) [8] observed that the length of the hydrophilic comonomer chains also influenced the protein exclusion. The authors synthesized two different polymers and the length of the chains was calculated by the number of comonomers grafted on each one. While the material with 2.8 comonomers excluded about $4.9 \%$ of proteins, the RAMIP with 17.1, excluded approximately $99 \%$.

The RAMIP hydrophilicity can be evaluated by the contact angle $(\theta)$ measurements. The means of the contact angle of a drop of water with the surface of the synthesized material is observed, if $\theta>90^{\circ}$, the material is hydrophobic, and if $\theta \leq 90^{\circ}$, the material is hydrophilic [32]. Some authors [33-38] employed this technique to prove that their RAMIPs have hydrophilic properties, being able to exclude proteins. As one example, Liu et al. (2020) [34] measured the contact angle of carbon dots@MIP and carbon dots@ RAMIP and the results showed a change in the hydrophilicity of the materials, angles of $102.0^{\circ}$ and $73.8^{\circ}$ were obtained, respectively. In addition, the Fourier Transform Infrared analysis is commonly used to demonstrate the incorporation of the comonomer in the MIPs.

Haginaka et al. (1999) [7] synthesized the first RAMIP, using a multi swelling polymerization method. The hydrophilic layer was obtained by a mixture of glycerol monomethacrylate and glycerol dimethacrylate, added in the reactional medium, $4 \mathrm{~h}$ after the beginning of the polymerization. The authors reported that 
the recognition sites remained unchanged even after the surface modification. The material was able to exclude macromolecules from biological samples, allowing the direct injection of the complex matrices in a column switching liquid chromatographic (LC) system. To verify the RAMIP capacity to exclude proteins, a solution of bovine serum albumin (BSA) was injected in the system and the peak area obtained without the column was taking as $100 \%$. Recoveries over $96.8 \%$ of BSA was achieved when the same BSA solution was injected in the system with the RAMIP column [7]. RAMIPs for the extraction of ibuprofen [12] and beta-blockers [39] from biological samples were reported by the same group.

RAMIPs grafting with poly(glyceryl monomethacrylate) were used to extract clenbuterol from human serum samples [9]. The macromolecule exclusion rates were higher than $88.9 \%$. In addition, glycerol dimethacrylate and 2-hydroxyethyl methacrylate were used to obtain RAMIPs able to extract beta-blockers from urine samples with good selective and high protein exclusion capacity [40]. In both papers, the samples were direct injected in column switching LC systems. These systems have been efficiently used, main due to the possibility to inject complex matrices without previous treatment (minimizing the sample manipulation and increasing the analytical frequency) [3]. However, some limitations of this procedure can be highlighted, as for example the difficult to uniformly pack the column with the synthesized material (creating preferred pathways), high column pressure or material leakage when particles with small diameters are used, and increment in the pressure along the analyses.

A selective RAMIP to parabens was synthesized via in situ polymerization in an open fused silica. The polymerization mixture was introduced into the silanized capillary and poly(glycerol dimethacrylate) was used to obtain a hydrophilic external layer. An in tube SPME procedure was performed to recovery the target molecules from breast milk samples. The capacity of the material to excluded matrix interferents was attested from the comparison of chromatograms obtained with sample preparation with MIP and RAMIP [41]. The limits of quantification (3-10 $\left.\mathrm{g} \mathrm{L}^{-1}\right)$ were close to those obtained with different sample preparation techniques: micro solid-phase extraction by packed sorbents (magnesium-aluminum layered double hydroxide coated on graphene oxide nanosheets), 10-15 $\mathrm{g} \mathrm{L}^{-1}$ [42], and dispersive liquid-liquid microextraction, $5 \mu \mathrm{g} \mathrm{L}^{-1}$ [43]. Additionally, the nanosheets could be used at least 25 times, while the authors did not report if the RAMIPs were reusable or not.

Zhang and co-works (2013) [44] obtained narrowly dispersed hydrophilic MIP particles with the surface grafted by poly(2-hydroxyethyl methacrylate) brushes. The synthesis was performed using a reversible addition-fragmentation chain transfer precipitation polymerization method, mediated by macromolecular chain-transfer agents. The results suggested that only those polymer brushes with a high enough molecular weight could prevent the accumulation of proteins on the material surface. In addition, the authors related that the hydrophilic RAMIP nanoparticles were compatible with different aqueous matrices, including, diluted and undiluted milk, bovine serum, and river water [44].

Besides the impression of low molecular weight analytes, some authors imprinted MIPs for proteins. However, MIPs for macromolecules can present some problems, such as poor mass transference and low selectivity, due to the high protein complexity, flexible conformation, and large molecular size. To circumvent these limitations, Li et al. (2015) [45] synthesized a magnetic RAMIP to BSA recognition using surface imprinted technique. In this methodology, bindings sites are located near or at the surface of the MIPS, facilitating the mobility of target molecule for into and out the sites. Additionally, 2-methacryloyloxyethyl phosphorylcholine was used as hydrophilic comonomer to prevent the adsorption of non-target proteins. The comonomer decreased the BSA adsorption, when compared with the MIP, but increased the selectivity to BSA, which is an advantage. In relation to the imprinted factors, there was an increment from 1.9 to 8.32 with the addition of $10 \%$ of the of 2-methacryloyloxyethyl phosphorylcholine, with a subsequently decreased to 1.44 , with the addition of $20 \%$ [45]. These results showed that the comonomer was favorable to the BSA extraction until a limit $(10 \%)$ and, from that, the adsorption was impaired, due to the large amount of 2-methacryloyloxyethyl phosphorylcholine on the RAMIP surface. The target protein selectivity was attested by the selectivity coefficient, which reached up to 1.63 , for human albumin and 9.14 , for lysozyme [45]. The lowest coefficient value for BSA/human serum albumin is probably because the 
high similarity between both molecules. The results demonstrated the suitable application of the surface imprinted technique, using RAMIPs for protein recognition. Additionally, the proposed strategy can be expected to improve the sensitivity of molecularly imprinted sensors for proteins.

A specific type of RAMIPs is obtained by using comonomers with epoxide rings that became hydrophilic after a chemical reaction. This process is performed after the RAMIP synthesis, by treating the polymers with acid solutions. The opening of the comonomer epoxide rings generates a high density of hydroxyl groups, giving rise to the hydrophilic external layer. Figure 2 shows a general synthesis scheme of these RAMIPs.

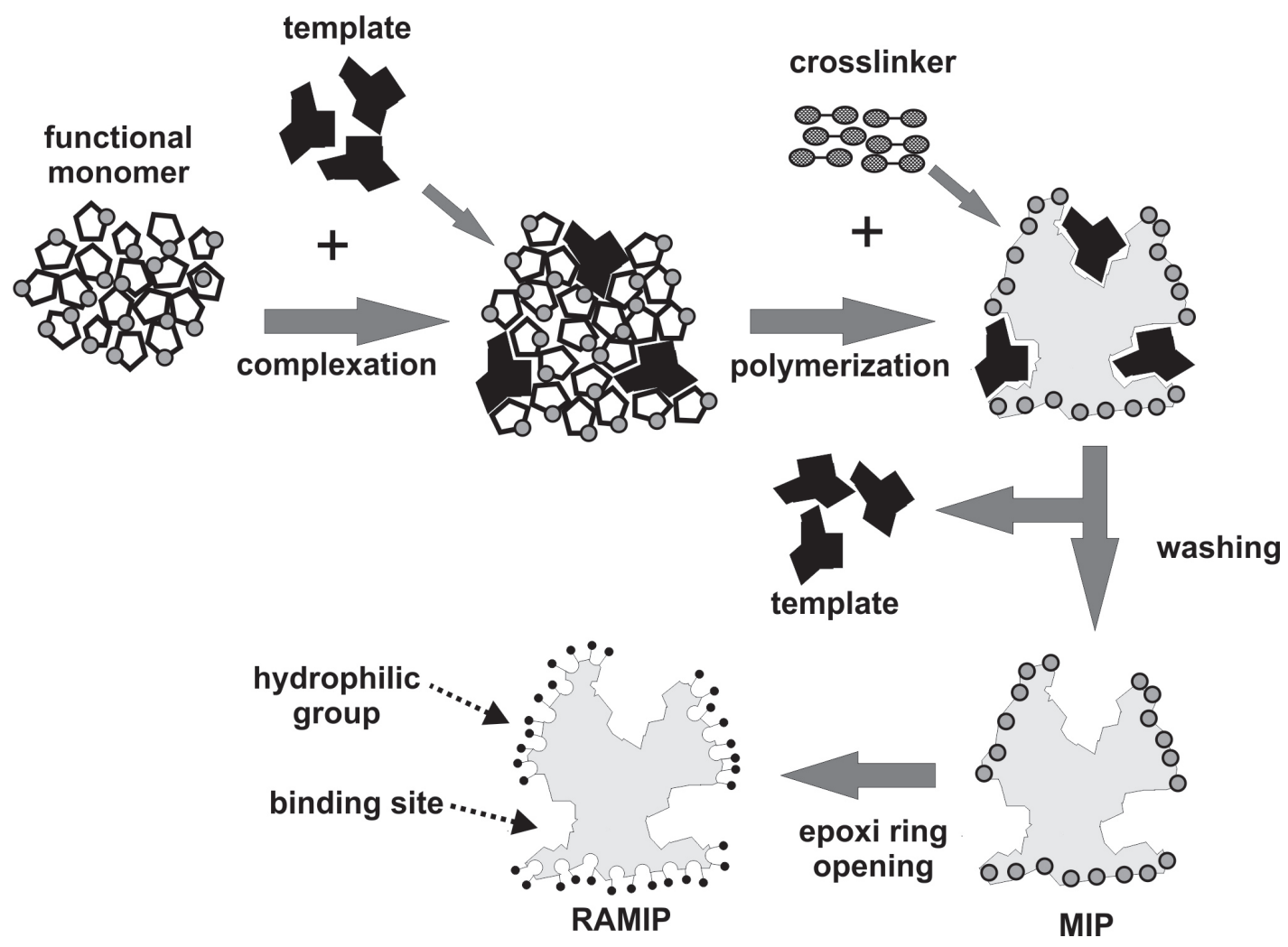

Figure 2. General synthesis scheme of the RAMIPs obtained by the grafting of comonomers that become hydrophilic after a chemical reaction. (Reprinted with permission from De Faria, H. D.; Abrão, L. C. de C.; Santos, M. G.; Barbosa, A. F.; Figueiredo, E. C. Anal. Chim. Acta, 2017, 959, pp 43-65 https://doi.org/10.1016/j. aca.2016.12.047 Copyright@ (2017), Elsevier.)

Puoci et al. (2009) [46] developed the first RAMIP using comonomers with epoxide rings. The synthesis occurred by a single step precipitation polymerization method, using glycidyl methacrylate as comonomer. Afterwards, the hydrophilic layer was created by mixing the dried polymers with perchloric acid solution $(10 \% \mathrm{v} / \mathrm{v})$. A protein exclusion rate of $97.5 \%$ was obtained after the percolation of a BSA aqueous solution into a solid phase extraction cartridge filled with the synthesized RAMIPs. The material was used for recognition and controlled/sustained release of $p$-acetaminophenol in gastrointestinal simulating fluid.

Other polymers have been obtained by using similar synthesis strategies introduced by Puoci et al. [46], and RAMIPs for ofloxacin [47], 2-methoxyestradiol [48], chloramphenicol [49], organophosphorus [5], and organochlorines [50] were obtained. In all cases, the MISPE technique was employed for the samples preparation, and the authors attested the selectivity and the ability to exclude macromolecules (imprinting factors ranging from 1.5 to 3.1 , and BSA exclusion rate ranging from 89.2 to $99.1 \%$ ). 
The modification of MIPs with silicates is also an alternative to obtain RAMIPs. A random freeradical polymerization and sol-gel process was used to synthesize an organic/inorganic hybrid RAMIP. Vinyltrimethoxysilane, tetraethyl-orthosilicate, and 3-glycidyloxypropyltrimethoxysilane were employed as coupling agent, inorganic precursor and comonomer, respectively [51,52]. The hybrid polymer was selective to folic acid and was used in MISPE procedures for the clean-up of milk powder samples. The authors reported that this material presented superior thermal stability, and high hardness when compared to the traditional polymers. However, the capacity to exclude proteins (about 55\% of exclusion [52]) was lower when compared to other RAMIPs. Giving the high concentration of proteins in milk samples, $45 \%$ of the no-excluded proteins can cause damages in the chromatographic systems, as well as problems in figures of merit. Thus, a pre-treatment was still necessary, in this case. Xu et al. (2010) [8] used silica as support to obtain a RAMIP for the extraction of sulfonamides from milk samples in a column switching LC system. The protein exclusion test was performed using the peak area without column as $100 \%$, and the exclusion rate was over $99 \%$. The material selectivity was confirmed by the imprinted factor of 2.7.

Magnetic materials also improve the dispersive solid phase extraction procedure, turning easier and faster the separation of the material from the sample. In this way, magnetic RAMIPs were synthesized and employed to the extraction of tetracyclines from milk and egg samples. Suitable selectivity for target molecules and protein exclusion capacity above $79.9 \%$ were related by the authors [37]. This methodology had a better detectability for tetracycline when compared with a solid phase-extraction using MIPs. Limits of detection of 1.0 and $25.0 \mu \mathrm{g} \mathrm{L}^{-1}$ were respectively obtained. In addition, the process without the RAM employed a previous protein precipitation step using $1 \mathrm{~mL}$ of hydrochloric acid and $15 \mathrm{~mL}$ of acetonitrile per $5 \mathrm{~mL}$ of milk [53].

The RAMIPs can also be used to turn fluorescent probes selective to one specific analyte. Liu et al. (2020) [34] developed a probe based on carbon dots@RAMIP selective to metronidazole. The synthesis was carried out in a single step, using glycidilmethacrylate as comonomer. The probe was used in equine serum samples and the metronidazole was quantified by the variation of fluorescence intensity. The authors reported that coexisting substances in the matrix have no significant influence on the analyte detection.

Both RAMIPs, obtained either by hydrophilic monomers or by monomers that become hydrophilic after a chemical reaction, presented satisfactory selectivity and protein exclusion capacities. A disadvantage can be the need of an additional synthesis step, in the second case. However, the growing use of these comonomers (e.g. glycidilmethacrylate) can be explained due to their lower inference in the polymerization complex, once its oxygen atom has lower capacity to form hydrogen bonds than free hydroxyl groups [46]. Additionally, 3-glycidyloxypropyltrimethoxysilane is consider a cheap silane coupling agent and can be grafted on the surface of silicon dioxide layers through a sol gel-reaction, allowing the obtaining of materials with silicates components [54].

The first RAMIPs synthesis strategies employed a multi swelling procedure, in which various steps previously to the polymerization are needed $[7,12,39]$. Along the years, the RAMIPs grafted with hydrophilic comonomers are being obtained principally by precipitation polymerization method $[5,40,46-50]$. This strategy is considered simple and provides particles with uniform size [47], becoming attractive to the researches.

In the case of urine samples [40], which is a matrix with low content of macromolecules, the use of RAMIPs was important to promote selectivity for the target molecules in aqueous media, given that the water interact more with hydrophilic layer than with the selective binding sites [55]. Additionally, the use of hybrid RAMIPs (organic/inorganic) open new possibilities to prepare selective materials, and the in-situ polymerization minimizes the difficult of columns uniform packaging. The protein imprinting in RAMIPs [45] turns able their use in sensor to diagnostics and as systems for depletion of abundant proteins. Finally, it is worth to point that most of the described synthesized materials were reusable for a certain period or number of cycles.

The applications of RAMIPs and comparisons in terms of figures of merit, selectivity, and ability to exclude macromolecules are summarized in Table I. 


\section{RAMIPS OBTAINED BY HYDROPHILIC COMONOMERS GRAFTING AND COVERING WITH BOVINE SERUM ALBUMIN}

In 2013, Figueiredo and co-workers [56] developed the first RAMIP obtained by hydrophilic comonomers (hydroxyethyl methacrylate and glycerol dimethacrylate) grafting, followed by covering with BSA chemically crosslinked. The material was packed in a column and coupled in an online column switching LC system. The procedure was selective to extract chlorpromazine (template, target molecule) from human plasma samples, with a protein exclusion capacity of about $99 \%$. Figure 3 shows a general synthesis scheme of this material.
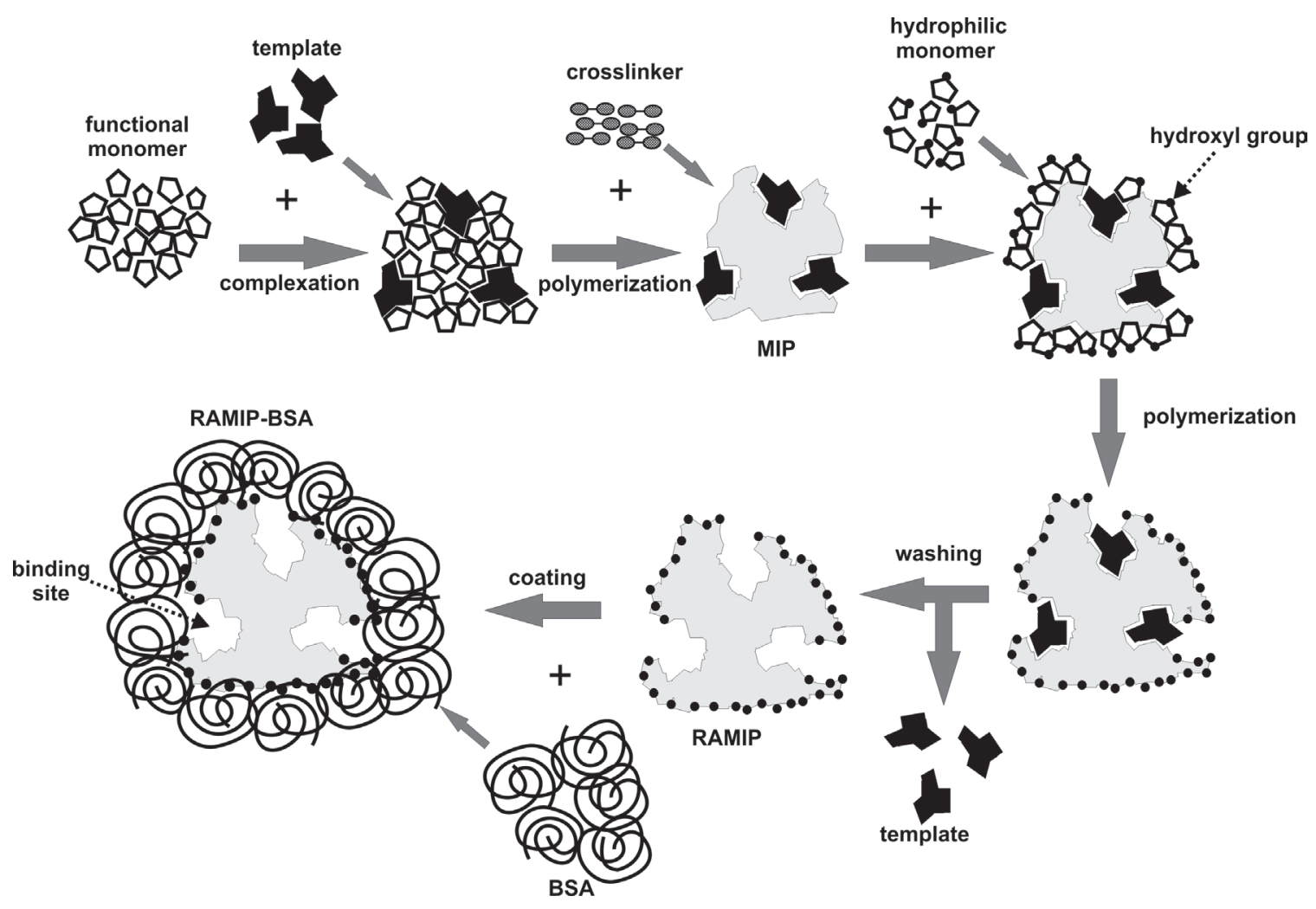

Figure 3. General synthesis scheme of the RAMIP obtained by hydrophilic comonomers grafting and covering with bovine serum albumin. (Reprinted with permission from De Faria, H. D.; Abrão, L. C. de C.; Santos, M. G.; Barbosa, A. F.; Figueiredo, E. C. Anal. Chim. Acta, 2017, 959, pp 43-65 https://doi.org/10.1016/j. aca.2016.12.047 Copyright@ (2017), Elsevier.)

The process of the BSA layer incorporation occurs after polymerization and with a clean polymer. Unlike what proceeds with the hydrophilic groups, the BSA layer is not going to build any chemical bond with the polymer surface. In place of this, a cross-linked BSA capsule is formed outside of the MIP particle. Glutaraldehyde has been used as crosslinker reagent, to bond the BSA molecules by reaction with their amino terminal groups (see Figure 4, steps 1 and 2). The high instability of obtained imine groups requests their conversion in amine groups using sodium borohydride as reducing agent (Figure 4, step 3). 
(1)

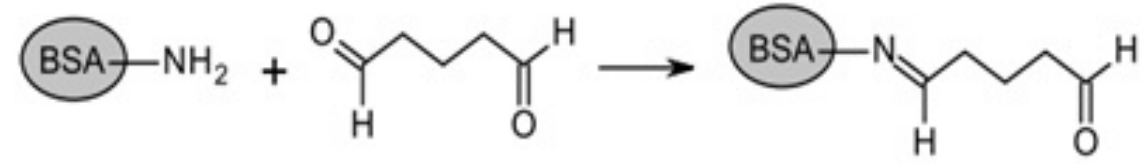

(2)

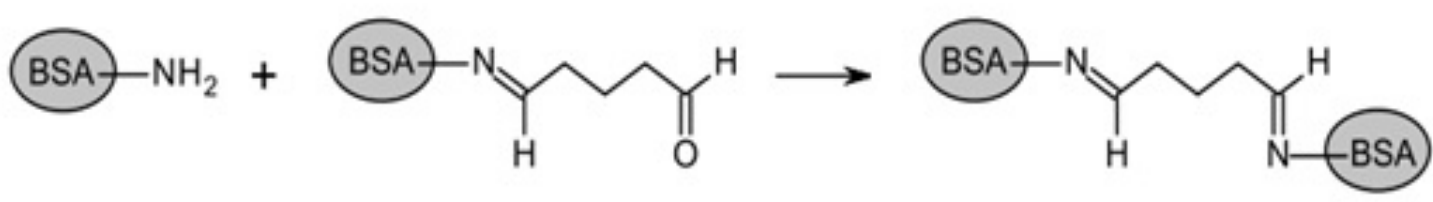

(3)
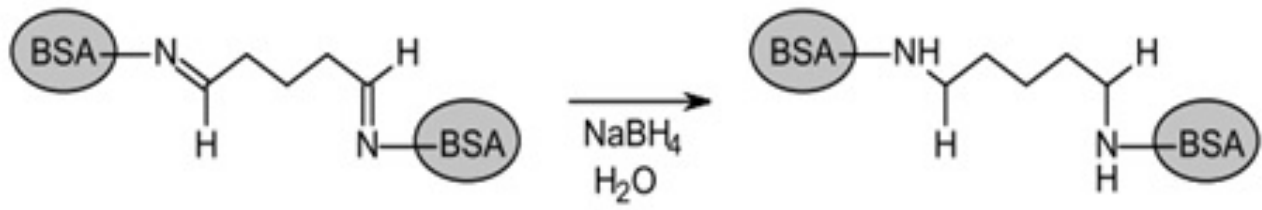

Figure 4. BSA coating reactions steps: (1) interaction between glutaraldehyde (crosslinker) and a BSA molecule; (2) bonding effect from glutaraldehyde on BSA molecules forming the crisscrossed BSA layer; (3) addition of a $\mathrm{NaBH}_{4}$ to reduce imine groups to amine groups.

The physical barrier imposed by the BSA capsule can avoid the direct contact of the macromolecules from the sample with the MIP surface. Additionally, the sample $\mathrm{pH}$ needs to be higher or lower than the BSA isoelectric point $(4.7)[3,57]$, in order to maintain both the proteins from the sample and from the BSA layer negatively or positively charged, respectively. In this case, an electrostatic repulsion prevails between the proteins, avoiding their interconnection. This is the principal event in the macromolecule exclusion.

Gomes et al. (2016) [57] investigated the influence of the $\mathrm{pH}$ in the protein exclusion capacity in restricted access carbon nanotubes (carbon nanotubes covered with a BSA layer). Despite to be a sorbent different of the MIP, the BSA layer is similar and the behavior in terms of protein exclusion can be compared. A protein exclusion capacity of $85 \%$ was obtained for pHs from 2.2 to 3.0 and from 5.6 to 7.0 . Meanwhile, this exclusion was about $45 \%$ for pHs from 3.5 to 5.2 , due to the proximity to the BSA isoelectric point. In other words, in a pH range close to the isoelectric point, the proteins from the BSA layer and the sample are not going to be charged and, consequently, there is no electrostatic repulsion between them. Moreover, this study proved how important is the $\mathrm{pH}$ value to promote protein exclusion by electrostatic repulsion using RAMs covered with BSA. Several works about RAMIPs covered with BSA were published, and the most part of them applied $\mathrm{pH} 7.0$ as a better analysis condition $[3,56,58,59]$. Table I summarizes applications of RAMIPs covered with BSA.

In 2016, da Silva et al. [60] synthetized a RAMIP to catch serotonin reuptake inhibitors from human plasma samples using fluoxetine as a template. Hydroxymethyl methacrylate and glycerol dimethacrylate were added during the MIP synthesis to promote hydrophilic properties to the material and, consequently, decrease the protein retention on the MIP surface. However, the authors also added a BSA cross-linked layer on the MIP surface to reach a higher protein exclusion percentage. The protein exclusion and the adsorption capacity for fluoxetine were $>99 \%$ and $68.5 \mathrm{mg} \mathrm{g}^{-1}$, respectively. The authors also highlighted the advantages of using the RAMIP with the BSA layer instead of those without the protein covering in a column switching LC system [60]. In the same year, another work applied a similar RAMIP in a column switching LC system, to determine ivermectin in meat samples [61]. Good results in terms of protein exclusion, selectivity, and figures of merit were also obtained. 
The RAMIP capacity for macromolecules elimination was also tested by Santos et al. in 2017 [13]. They used a column switching system, coupled to a mass spectrometry to determine tricyclic antidepressants in human plasma. The polymer was synthesized by using glycidyl methacrylate as hydrophilic co-monomer and was covered with BSA layer, differently than the previous works. In order to evaluate the influence of the glycidyl methacrylate and BSA presence, the RAMIPs obtained with the co-monomer and with the co-monomer + BSA layer were compared. The protein exclusion capacities were around $87 \%$ and $100 \%$, respectively. This fact indicates that the presence of the BSA external layer was important to improve the RAMIP efficiency [13].

A similar strategy was proposed by Sun et al. (2019) [62] using glycidyl methacrylate and BSA to synthetize a RAMIP and immobilize it on the surface of a mesoporous UiO-66- $\mathrm{NH}_{2}$ metal-organic framework. The authors called the material UiO-66- $\mathrm{NH}_{2} @ \mathrm{RAMIP@BSA}$. Ofloxacin was used as a template and the material was applied to determine fluoroquinolone antibiotics in bovine serum samples. The authors highlighted the use of a hydrophilic bilayer (with hydrophilic groups and the BSA layer) were the better strategy to obtain an excellent protein exclusion efficiency. For that, they compared the protein exclusion capacity of the materials UiO-66- $\mathrm{NH}_{2} @ M I P$ (only MIP), UiO-66- $\mathrm{NH}_{2} @ \mathrm{RAMIP}$ (MIP + hydrophilic groups) and of UiO-66- $\mathrm{NH}_{2} @ \mathrm{RAMIP} @ B S A(\mathrm{MIP}+$ hydrophilic groups + BSA) and the percentage obtained were 36.5, 96.0, and 99.4, respectively. Moreover, the adsorption capacity of UiO-66- $\mathrm{NH}_{2} @ \mathrm{RAMIP@BSA} \mathrm{was}$ high as $50.55 \mathrm{mg} \mathrm{g}^{-1}$. Also, the author claimed that the material was better in comparison with others from the literature.

Despite the works involving RAMIPs are mostly applied to protein-rich samples, Oliveira et al. (2019) [38] developed two works about RAMIP to be used in urine samples. In one of their works, they obtained a restricted access mesoporous molecularly imprinted polymer (MMIP) coated with hydrophilic monomers and BSA. This material (called RA-MMIP-HM-BSA) was applied to extract estrone and estriol in pregnant volunteers' urine samples. The analyses were performed by microextraction by packed sorbent followed by a HPLC-UV system. The results to the protein exclusion test were $85 \%$ for MMIP, 91\% for RA-MMIP$\mathrm{HM}$, and $99 \%$ for RA-MMIP-HM-BSA which means that a material doubly coated can perform better than a material with one hydrophilic layer [38], as already observed in previous described works [59]. Additionally, the obtained quantification limit $\left(10.0 \mu \mathrm{g} \mathrm{L}^{-1}\right)$ for estriol was lower than the one achieved using a carbon paste electrode modified with ferrimagnetic nanoparticles for voltammetric detection $\left(241.0 \mu \mathrm{L} \mathrm{L}^{-1}\right)$ [63]; but higher than the one obtained using a multiple monolithic fiber solid-phase microextraction based on a polymeric ionic liquid, for urine preparation and high-performance liquid chromatography with a diode array detector $\left(0.15 \mu \mathrm{g} \mathrm{L}^{-1}\right)$ [64].

In the second work a magnetic mesoporous molecularly imprinted polymer (MMMIP) coated with a bihydrophilic layer (HM+BSA) was synthetized to determine ethinylestradiol and estradiol in urine samples from voluntaries on hormonal contraceptive use. The material called RA-MMMIP-HM-BSA showed a good protein exclusion capacity $(99.76 \%)$ in comparison with the MMMIP (84.88\%) and RA-MMMIP-BSA $(96.76 \%)$, as well as an excellent efficiency for extracting both studied hormones [36]. 


\section{RAMIPS OBTAINED EXCLUSIVELY BY COVERING WITH BOVINE SERUM ALBUMIN}

RAMIPs can also be obtained by covering of conventional MIPs with BSA layer, without the use of hydrophilic monomers (Figure 5).

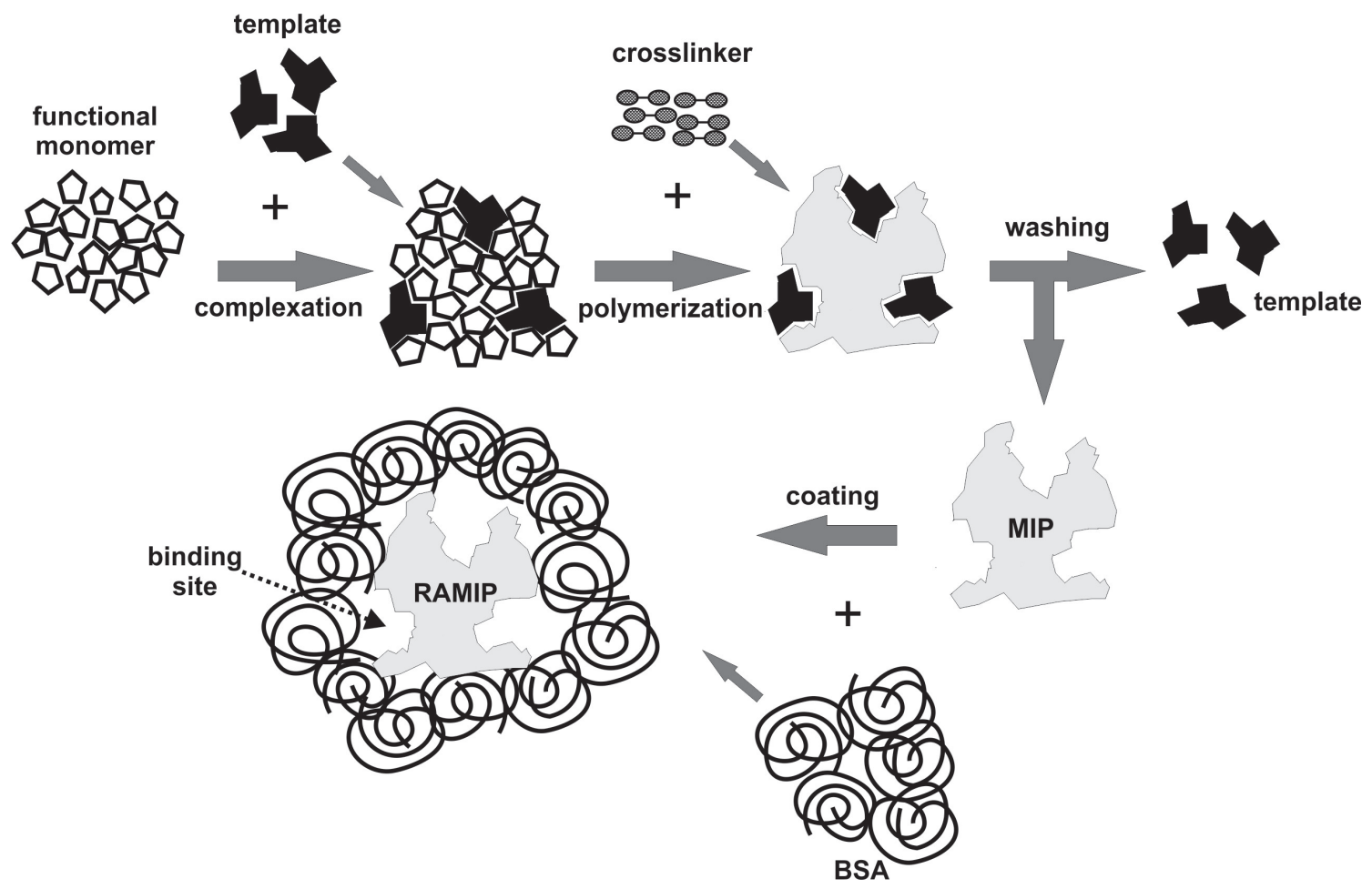

Figure 5. General synthesis scheme of the RAMIP obtained by covering with bovine serum albumin. (Adapted with permission from De Faria, H. D.; Abrão, L. C. de C.; Santos, M. G.; Barbosa, A. F.; Figueiredo, E. C. Anal. Chim. Acta, 2017, 959, pp 43-65 https://doi.org/10.1016/j.aca.2016.12.047 Copyright@ (2017), Elsevier.)

This strategy has been presented in some works since $2019[58,65,66]$. Abrão and Figueiredo coated a previous synthesized MIP fiber with BSA, for use in the extraction of benzodiazepines and analogues from plasma samples (Figure 6). According to the authors, this fiber was the first based on RAMIP for SPME. It was synthetized into glass capillary tubes, removed, and treated with BSA according to previous works $[56,65]$. The solvent volume in the synthesis mixture was an important variable. Low volumes resulted in vitrified and inflexible fibers, whereas high volumes resulted in a powder (non-monolithic polymer). RAMIP fiber remained stable up to $250{ }^{\circ} \mathrm{C}$, being possible it used in gas chromatography with thermal desorption. Fiber selectivity was attested, and its protein exclusion tax was about $98 \%$ [65]. 


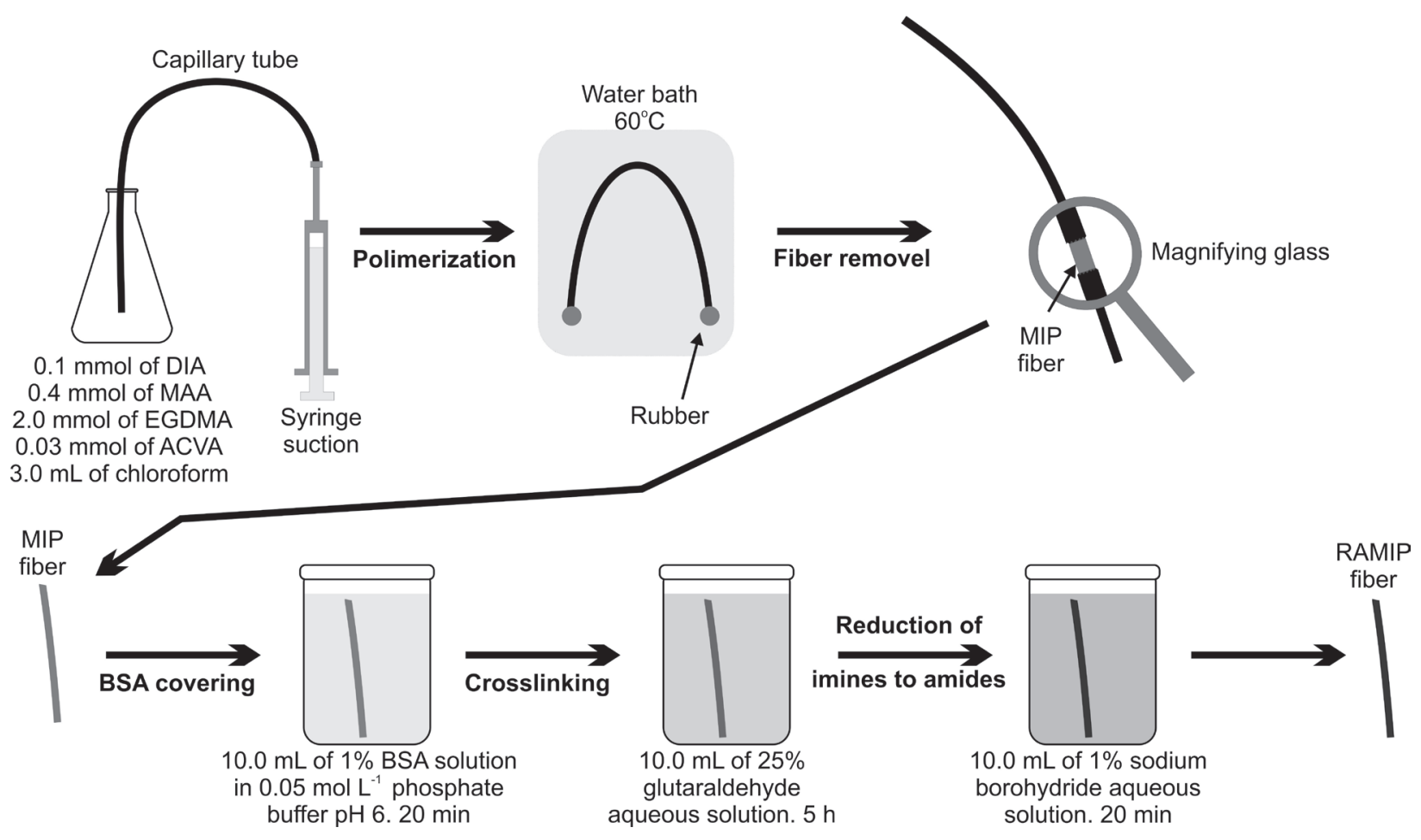

Figure 6. Schematic figure from Abrão and co-workers work [30] with an explanation about their RAMIP fibers synthesis. (The authors are thankful to Royal Society of Chemistry for permission to reproduce this figure from L.C.D.C. Abrão and E.C. Figueiredo, Analyst, 2019, 144, 4320, https://doi.org/10.1039/C9AN00444K)

At the same line, Wang et al. (2019) [65] modified stainless steel fibers to coat them with a RAMIP based on BSA layer to select hesperitin and its metabolites [66]. 3-(tri-methoxysilyl) propyl methacrylate and dopamine were used to promote a bridge between the stainless fiber and the MIP, that was coated with BSA following the Moraes et al. protocol $[56,66]$. RAMIP fiber was used for an in vivo assay. The rats used were kept alive during all the procedure, and the fibers were exposed inside their livers. Because of that, one of the authors' concern was the fiber performance to exclude BSA and bovine hemoglobin as well. The RAMIP could eliminate about $98.96 \%$ of BSA and $94.80 \%$ of bovine hemoglobin while the MIP fibers eliminated only $59.99 \%$ and $47.08 \%$, respectively [66].

Mendes et al. (2020) [58] used a similar strategy to attach a RAMIP on $\mathrm{Fe}_{3} \mathrm{O}_{4}$ nanoparticles surface [66]. Tetraethyl orthosilicate provides silanol groups which can be attached to a nanoparticle surface and also prepares the metal to receive the 3-(trimethoxysilyl) propyl methacrylate, the second reagent. It is important to highlight that coating nanoparticle surfaces is a strategy to decrease the dipolar attraction among them. This improves their dispersion capacity, protects them from the oxidation process and reduces the nanoparticles aggregation [36,58]. The 3-(trimethoxysilyl) propyl methacrylate offers the methacrylic groups to bind the iron nanoparticle (inorganic material) with the MIP (organic material) during the polymerization. The BSA layer was added after the polymerization step. The magnetic susceptibility of the RAMIP allowed its use in magnetic dispersive SPE of nicotine from biological fluids [58]. The protein exclusion taxes were 79 and $99 \%$ for MIP and RAMIP, respectively. RAMIP captured more nicotine (template) than cotinine, lidocaine, and cocaine, attesting the presence of the selective binding sites. However, the selectivity of RAMIP was lower in comparison with MIP (without the BSA layer). This result was explained due to the possible obstruction of some selective binding sites by the BSA layer as well as due to possible unspecific retention of molecules in the BSA structure [58]. 
To clarify the unspecific retention of analytes in the BSA, Rosa et al. (2019) [67] tested if restrictedaccess nanoparticles from BSA (obtained by coacervation) would be able to adsorb drugs that have high and low affinity for proteins. The particles presented capacity to adsorb the analytes as well as to exclude proteins, being possible its use in biological sample preparation.

According to all the papers described, covering a MIP with BSA is a good strategy to exclude proteins from non-treated samples such as plasma, serum, blood, and milk, for instance, reaching about $100 \%$ of protein exclusion. Moreover, in comparison with the hydrophilic monomers' strategy, the BSA layer can be added any time after the material is synthetized.

Another advantage is that the BSA layer can promote a biocompatibility and stability to be applied on in vivo experiments with no damage for the individual. However, in some cases, the BSA layer can prejudice the MIP selectivity and the bidding sites adsorption. So, it is up to the researcher to decide which RAM strategy is the best to apply on the MIP to reach satisfactory results.

\section{RAMIPS OBTAINED BY OTHER STRATEGIES}

Hua et al. (2011) [68] used biocompatible carbohydrates to obtain a hydrophilic layer in a RAMIP selective to phenobarbital. The alcoholysis process was performed afterward the synthesis to deprotected the blocking groups of the carbohydrates, introducing the sugar moiety in the external layer of MIP particles. The authors related that uniform sized polymers were obtained and that the recognition sites of phenobarbital were unchanged even after the surface modification. In addition, more than $85 \%$ of BSA could be recovery from the surface modified material, attesting its capacity to exclude macromolecules [68]. However, it is important to point out that other RAMIPs have presented better protein exclusion capacities $[37,39,48,58,60,62,65]$.

\section{RAMIPS COMPARISION: APPLICATIONS AND CHARACTERISTICS}

As demonstrated by the examples, RAMIPs obtained by hydrophilic comonomers grafting, protein covering, or both strategies were suitable for the biological matrices sample preparation. The materials were able to selectively extract the analyte(s) and exclude macromolecules concomitantly. In addition, the authors did not report difficulties in the synthesis repeatability or problems with clogging when column switching systems were used. The comparison between the applications of RAMIPs and the characteristics from each type of them can be found in Tables I and II, respectively. 
Table I. Applications of RAMIPs

\section{RAMIPs obtained by hydrophilic comonomers grafting}

\begin{tabular}{|c|c|c|c|c|c|c|c|c|c|c|}
\hline Monomer(s) & Material & Analyte(s) & Method & Sample(s) & LOD & LOQ & $\begin{array}{l}\text { Protein } \\
\text { exclusion } \\
\text { rate }\end{array}$ & IF & Reusability & Ref. \\
\hline $\mathrm{GMA}^{*}$ & RAM-MIM & Organophosphorus & MISPE-GC-FPD & Honey & $0.5-1.9 \mu \mathrm{g} \mathrm{L}^{-1}$ & - & - & 3.1 & - & [5] \\
\hline $\begin{array}{l}\text { GMMA } \\
\text { GDMA }\end{array}$ & RAMIP & (S)-naproxen & CS -LC-UV & Serum & - & - & $\geq 96.8$ & - & - & [7] \\
\hline $\mathrm{GMA}^{*}$ & RAMIP & Sulfonamides & CS -LC-UV & Bovine milk & $0.2-0.8 \mu \mathrm{g} \mathrm{L}^{-1}$ & $\begin{array}{c}0.7-2.7 \\
\mu \mathrm{g} \mathrm{L}^{-1}\end{array}$ & $\geq 99.0$ & 2.7 & - & {$[8]$} \\
\hline GMMA & $\begin{array}{l}\text { RAMIP } \\
\text { monolithic } \\
\text { column } \\
\end{array}$ & Clenbuterol & CS-LC-UV & Human serum & $0.7 \mu \mathrm{g} \mathrm{L}^{-1}$ & $2.0 \mu \mathrm{g} \mathrm{L}^{-1}$ & $\geq 90.0$ & 7.2 & 15 months & [9] \\
\hline $\begin{array}{l}\text { GMMA } \\
\text { GDMA }\end{array}$ & RAMIP & Ibuprofen & CS -LC-UV & Rat plasma & $50 \mu \mathrm{g} \mathrm{L}^{-1}$ & $200 \mu \mathrm{L} \mathrm{L}^{-1}$ & $\sim 100$ & - & $\begin{array}{c}\sim 500 \\
\text { injections }\end{array}$ & {$[12]$} \\
\hline $\mathrm{GMA}^{*}$ & $\begin{array}{l}\text { CDs@ } \\
\text { RAMIPs } \\
\text { probe }\end{array}$ & Metronidazole & $\begin{array}{l}\text { Fluorescence } \\
\text { intensity }\end{array}$ & Equine serum & $17.4 \mu \mathrm{g} \mathrm{kg}^{-1}$ & - & 95.5 & - & - & [34] \\
\hline $\mathrm{GMA}^{*}$ & M- RAMIP & Tetracyclines & MSPE-LC-UV & Milk and egg & $\begin{array}{c}1.03-2.67 \\
\mu g \mathrm{~kg}^{-1}\end{array}$ & $\begin{array}{c}3.46-8.97 \\
\mu g \mathrm{~kg}^{-1}\end{array}$ & 99.4 & $\sim 2.3$ & $\begin{array}{l}\text { At least } 6 \\
\text { times }\end{array}$ & [37] \\
\hline $\begin{array}{l}\text { GMMA } \\
\text { GDMA }\end{array}$ & RAMIP & Beta blocker drugs & CS LC-UV & Rat plasma & - & $12.5 \mu \mathrm{g} \mathrm{L}^{-1}$ & $\geq 97.0$ & - & - & [39] \\
\hline $\begin{array}{l}\text { HEMA } \\
\text { GDMA }\end{array}$ & RAMIP & Beta blocker drugs & CS -LC-MS/MS & Urine & $0.1-1.0 \mu \mathrm{g} \mathrm{L}^{-1}$ & $1.0-3.0 \mu \mathrm{g} \mathrm{L}^{-1}$ & - & $\sim 1.2$ & $\sim 150$ cycles & {$[40]$} \\
\hline GDMA & RAMIP & $\begin{array}{l}\text { Methyl, ethyl, propyl, } \\
\text { butylparaben }\end{array}$ & $\begin{array}{c}\text { in-tube SPME-LC- } \\
\text { MS/MS }\end{array}$ & $\begin{array}{l}\text { Breast milk } \\
\text { samples }\end{array}$ & - & $3-10 \mu g L^{-1}$ & $\begin{array}{l}\quad \geq 67 \\
\text { (exclusion of } \\
\text { endogenous } \\
\text { compounds) }\end{array}$ & $8.0-14.0$ & - & [41] \\
\hline PHEMA & RAMIP & $\begin{array}{c}\text { 2,4-dichlorophenoxyacetic } \\
\text { acid (1 study) and } \\
\text { propranolol ( } 2 \text { study) }\end{array}$ & - & $\begin{array}{l}\text { River water, } \\
\text { milk, and bovine } \\
\text { serum }\end{array}$ & - & - & & - & - & {$[44]^{\mathrm{a}}$} \\
\hline MPC & M-RAMIP & BSA & - & - & - & - & - & 8.32 & - & {$[45]^{\mathrm{b}}$} \\
\hline $\mathrm{GMA}^{*}$ & RAMIP & $p$-acetaminophenol & - & - & - & - & 95.7 & - & - & {$[46]^{\mathrm{c}}$} \\
\hline $\mathrm{GMA}^{*}$ & RAMIP & Ofloxacin & MISPE-LC-UV & Milk & - & - & 92.4 & $\sim 1.8$ & 10 cycles & {$[47]^{\mathrm{d}}$} \\
\hline $\mathrm{GMA}^{*}$ & RAMIP & 2-methoxyestradiol & MISPE-LC-UV & Rat plasma & $20 \mu \mathrm{g} \mathrm{L}^{-1}$ & $60 \mu \mathrm{g} \mathrm{L}^{-1}$ & 93.5 & $\sim 1.5$ & 9 cycles & [48] \\
\hline
\end{tabular}


Table I. Applications of RAMIPs (Continuation)

RAMIPs obtained by hydrophilic comonomers grafting

\begin{tabular}{|c|c|c|c|c|c|c|c|c|c|c|}
\hline Monomer(s) & Material & Analyte(s) & Method & Sample(s) & LOD & LOQ & $\begin{array}{l}\text { Protein } \\
\text { exclusion } \\
\text { rate }\end{array}$ & IF & Reusability & Ref. \\
\hline $\mathrm{GMA}^{*}$ & RAMIP & Chloramphenicol & MISPE-LC-UV & Bovine serum & $1.2 \mu \mathrm{g} \mathrm{L}^{-1}$ & - & $\geq 92.6$ & $\sim 3.0$ & $\begin{array}{l}\text { At least } 8 \\
\text { times }\end{array}$ & [49] \\
\hline $\mathrm{GMA}^{*}$ & RAMIP & Organochlorides & MISPE-GC-EDC & Pork & $1-2 \mu \mathrm{g} \mathrm{kg}^{-1}$ & 5. $\mu \mathrm{g} \mathrm{kg}^{-1}$ & 97.3 & $\sim 2.5$ & $\begin{array}{l}\text { At least } 4 \\
\text { cycles }\end{array}$ & {$[50]$} \\
\hline GPTMS* & $\begin{array}{c}\text { RAMIP/ } \\
\mathrm{SiO}_{2} \text { hybrid } \\
\text { material }\end{array}$ & Folic acid & MISPE-LC-PDA & - & - & - & - & $\sim 1.2$ & $\begin{array}{l}\text { At least } 120 \\
\text { times }\end{array}$ & {$[51]$} \\
\hline GPTMS* & $\begin{array}{c}\text { RAMIP/ } \\
\mathrm{SiO}_{2} \text { hybrid } \\
\text { material }\end{array}$ & Folic acid & MISPE-LC-DAD & Milk powder & $1.45 \mu \mathrm{g} \mathrm{L}^{-1}$ & $4.83 \mu \mathrm{g} \mathrm{L}^{-1}$ & 53.3 & - & $\begin{array}{l}\text { At least } 100 \\
\text { times }\end{array}$ & {$[52]$} \\
\hline $\begin{array}{l}\text { HEMA } \\
\text { GDMA }\end{array}$ & RAMIP & Oxprenolol & - & Human plasma & - & - & 87.8 & $\sim 1.2$ & - & [59] \\
\hline $\mathrm{GMA}^{*}$ & RAMIP & Caffeine & - & - & - & - & $\geq 73.9$ & - & $\begin{array}{l}\text { At least } 5 \\
\text { times }\end{array}$ & {$[69]^{\mathrm{e}}$} \\
\hline \multicolumn{11}{|c|}{ RAMIPs obtained by comonomers and BSA covering } \\
\hline Monomer(s) & $\begin{array}{l}\text { Material } \\
\text { (named } \\
\text { according to } \\
\text { the authors) }\end{array}$ & Analyte(s) & Method & Sample(s) & LOD & LOQ & $\begin{array}{l}\text { Protein } \\
\text { exclusion } \\
\text { rate }\end{array}$ & IF & Reusability & Ref. \\
\hline $\begin{array}{l}\text { GMA } \\
\text { BSA }\end{array}$ & RAMIP & Tricyclic antidepressants & CS-LC-MS/MS & Human plasma & - & $15 \mu \mathrm{g} \mathrm{L}^{-1}$ & $\sim 100$ & - & - & {$[13]$} \\
\hline $\begin{array}{l}\text { HEMA } \\
\text { GDMA } \\
\text { BSA }\end{array}$ & M-RAMIP & Ethinylestradiol and estradiol & $\begin{array}{l}\text { MSPE dispersive- } \\
\text { LC-UV }\end{array}$ & Human urine & - & $80 \mu \mathrm{g} \mathrm{L}^{-1}$ & 99.76 & - & $\begin{array}{l}\text { At least } 5 \\
\text { times }\end{array}$ & [36] \\
\hline $\begin{array}{l}\text { HEMA } \\
\text { GDMA } \\
\text { BSA } \\
\end{array}$ & M-RAMIP & Estrone and estriol & MEPS-LC-UV & Human urine & - & $100 \mu \mathrm{g} \mathrm{L}^{-1}$ & 99.0 & - & Only 1 use & [38] \\
\hline $\begin{array}{l}\text { HEMA } \\
\text { GDMA } \\
\text { BSA }\end{array}$ & RAMIP & Chlorpromazine & CS-LC-UV & Human plasma & - & $30 \mu \mathrm{g} \mathrm{L}^{-1}$ & 99.0 & 3.8 & 90 cycles & {$[56]$} \\
\hline $\begin{array}{l}\text { HEMA } \\
\text { GDMA } \\
\text { BSA }\end{array}$ & RAMIP & Oxprenolol & - & Human plasma & - & - & 98.7 & $\sim 1.2$ & - & [59] \\
\hline
\end{tabular}


Table I. Applications of RAMIPs (Continuation)

\begin{tabular}{|c|c|c|c|c|c|c|c|c|c|c|}
\hline Monomer(s) & Material & Analyte(s) & Method & Sample(s) & LOD & LOQ & $\begin{array}{l}\text { Protein } \\
\text { exclusion } \\
\text { rate }\end{array}$ & IF & Reusability & Ref. \\
\hline $\begin{array}{l}\text { HEMA } \\
\text { GDMA } \\
\text { BSA }\end{array}$ & RAMIP & Serotonin reuptake inhibitors & CS-LC-UV & human plasma & - & $20 \mu \mathrm{g} \mathrm{L}^{-1}$ & $\sim 100$ & $\sim 1.5$ & - & {$[60]$} \\
\hline $\begin{array}{l}\text { HEMA } \\
\text { GDMA } \\
\text { BSA }\end{array}$ & RAMIP & Ivermectin & CS-LC-UV & Meat & $30 \mu \mathrm{kg}^{-1}$ & $50 \mu \mathrm{g} \mathrm{kg}^{-1}$ & $\sim 100$ & - & - & {$[61]$} \\
\hline $\begin{array}{l}\text { GMA } \\
\text { BSA }\end{array}$ & $\begin{array}{c}\text { UiO-66- } \\
\mathrm{NH}_{2} @ \\
\text { RAMIP@ } \\
\text { BSA }\end{array}$ & Ofloxacin and enrofloxacin & MISPE-LC-UV & Bovine serum & $15.6 \mu \mathrm{g} \mathrm{L}^{-1}$ & - & 99.4 & $\sim 3.1$ & - & {$[62]$} \\
\hline
\end{tabular}

RAMIPs obtained by BSA covering

\begin{tabular}{|c|c|c|c|c|c|c|c|c|c|c|}
\hline Protein & Material & Analyte(s) & Method & Sample(s) & LOD & LOQ & $\begin{array}{l}\text { Protein } \\
\text { exclusion } \\
\text { rate }\end{array}$ & IF & Reusability & Ref. \\
\hline BSA & M-RAMIP & Nicotine & $\begin{array}{l}\text { MSPE dispersive - } \\
\text { LC-UV and GC-MS }\end{array}$ & Human plasma & - & - & 99.0 & $\sim 1.4$ & $\begin{array}{c}50 \\
\text { extractions } \\
\text { cycles } \\
\end{array}$ & {$[58]$} \\
\hline BSA & RAMIP & Oxprenolol & - & Human plasma & - & - & 87.3 & $\sim 1.2$ & - & [59] \\
\hline BSA & RAMIP fiber & Benzodiazepines & SPME-LC-DAD & Human plasma & $5-30 \mu \mathrm{g} \mathrm{L}^{-1}$ & $\begin{array}{r}15-100 \\
\mu g L^{-1}\end{array}$ & 98.0 & - & - & {$[65]$} \\
\hline BSA & RAMIP fiber & $\begin{array}{l}\text { Hesperetin and its } \\
\text { metabolites }\end{array}$ & $\begin{array}{c}\text { SPME - UPLC-MS/ } \\
\text { MS }\end{array}$ & Rat livers in vivo & $20 \mu \mathrm{g} \mathrm{L}^{-1}$ & $50 \mu \mathrm{g} \mathrm{L}^{-1}$ & $\geq 94.8$ & $\sim 3.1$ & - & {$[66]$} \\
\hline \multicolumn{11}{|c|}{ RAMIPs obtained by other strategies } \\
\hline Monomer(s) & $\begin{array}{l}\text { Material } \\
\text { (named } \\
\text { according to } \\
\text { the authors) }\end{array}$ & Analyte(s) & Method & Sample(s) & LOD & LOQ & $\begin{array}{l}\text { Protein } \\
\text { exclusion } \\
\text { rate }\end{array}$ & IF & Reusability & Ref. \\
\hline Glycomonomer & glyco-MIP & Phenobarbital & MISPE-LC-UV & Calf serum & - & - & $\geq 85.0$ & - & - & [68] \\
\hline
\end{tabular}

*The comonomer has epoxide rings that become hydrophilic after a chemical reaction. 
Continuation of Table I footer:

BSA: bovine serum albumin; CD: carbon dot; CS: column switching; DAD: diode array detector; EDC: eletron capture detector; FPD: flame photometric detector; GC: gas chromatography;

GDMA: glycerol dimethacrylate; GMA: glycidilmethacrylate; GMMA: glycetol monomethacrylate; GPTMS: 3-glycidyloxypropyltrimethoxysilane; HEMA: hydroxymethylmethacrylate;

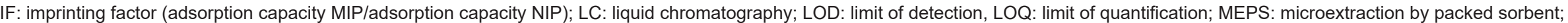

MIP: molecularly imprinting polymer; MISP: molecularly imprinted solid phase extraction; MPC: 2-methacryloyloxyethyl phosphorylcholine;

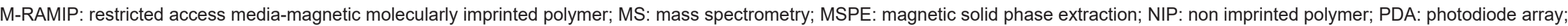
PHEMA: poly(2-hydroxyethyl methacrylate); RAM-MIMM: restricted access materials-molecularly imprinted magnetic micro- spheres; RAMIP: restricted access molecularly imprinting polymer; SPE: solid phase extraction; SPME: solid phase microextraction; UV: ultraviolet-visible detector.

aThe paper focus in the material compatibility with the different complex matrices.

${ }^{\text {b} T h e ~ p a p e r ~ a i m e d ~ t o ~ s t u d y ~ t h e ~ a d s o r p t i o n ~ c a p a c i t y ~ a n d ~ s e l e c t i v i t y ~ o f ~ t h e ~ s y n t h e s i z e d ~ m i c r o s p h e r e s . ~}$

'The paper focus in the recognition and controlled/sustained release. Initial investigations to drug delivery systems.

${ }^{\mathrm{d}}$ The paper evaluated the best synthesis conditions to obtain the final material.

eThe paper compares different synthesis conditions and does not focus on the material application.

Table II. Comparison of the characteristics of each type of RAMIP

\section{Characteristics}

Advantages

\section{RAMIPs obtained by}

Protein covering

$>$ The external BSA layer confers more

$>$ The hydrophilic comonomers contributed biocompatibility to the material.

to better molecular recognition in aqueous media [59].

$>$ The comonomers can be included in the polymerization flask, Thus, some RAMIPs are obtained with a one-step synthesis.

$>$ It was already employed in in vivo studies [66].

> Any synthesized MIP can be functionalized with the BSA layer. Thus, MIPs can be transformed into RAMIPs even after their synthesis.

\section{Both strategies}

$>$ A higher protein exclusion rate can be obtained due to the combination of the protein exclusion mechanisms (physical barriers, hydrophilic layer, and electrostatic repulsion).
$>$ The presence of the comonomers can interfere in the formation of the prepolymerization complex [46].

$>$ The opening ring reaction, when necessary, demands a synthesis step of $24 \mathrm{~h}$.
> Limited $\mathrm{pH}$ range for protein exclusion.

$>$ The BSA can interact non-specifically with some drugs present in the samples [67].
$>$ Limited $\mathrm{pH}$ range for electrostatic repulsion mechanism.

$>$ Demand more synthesis steps to the functionalization 
Table II. Comparison of the characteristics of each type of RAMIP (Continuation)

\begin{tabular}{|c|c|c|c|}
\hline \multicolumn{2}{|l|}{ Characteristics } & \multicolumn{2}{|l|}{ RAMIPs obtained by } \\
\hline & Hydrophilic comonomers & Protein covering & Both strategies \\
\hline Exclusion $\mathrm{pH}$ range & $\begin{array}{l}\text { > Most of the authors did not report that } \\
\text { the protein exclusion rates were impaired } \\
\text { by the sample pH. One exception in the } \\
\text { work of Sanbe and Haginaka (2003) [39]. }\end{array}$ & $\begin{array}{l}\text { > Do not have a suitable protein exclusion } \\
\text { rate in the pH range of } 3.5 \text { to } 5.2 \text {, due to } \\
\text { the proximity of the BSA isoelectric point } \\
{[57] \text {. }}\end{array}$ & $\begin{array}{l}\text { > Do not have the electrostatic repulsion } \\
\text { mechanism in the pH range of } 3.5 \text { to } 5.2 \text {. }\end{array}$ \\
\hline $\begin{array}{l}\text { Non-specific } \\
\text { interactions }\end{array}$ & $\begin{array}{l}\text { > Some authors suggested that the } \\
\text { hydroxyl groups can be bound non- } \\
\text { specifically with some compounds beyond } \\
\text { the analyte(s) [3]. }\end{array}$ & $\begin{array}{l}>\text { It was demonstrated that the BSA } \\
\text { can extract some drugs from untreated } \\
\text { biological samples [67]. Therefore, non- } \\
\text { specific interactions can occur. }\end{array}$ & $\begin{array}{l}>\text { Non-specific interactions can occur in } \\
\text { both functionalization layers. }\end{array}$ \\
\hline Reusability* & $\begin{array}{l}\text { > Eleven of the exemplified papers } \\
\text { reported the reusability of this type of } \\
\text { RAMIP. The number of extraction cycles } \\
\text { using the same material without losses in } \\
\text { efficiency, ranged from } 4 \text { to } 500 \text {. }\end{array}$ & $\begin{array}{l}\text { > Just one of discussed papers reported } \\
\text { the reusability of this type of RAMIP. } \\
\text { The material was efficiently used in } 50 \\
\text { extraction cycles. }\end{array}$ & $\begin{array}{l}>\text { Three works brought information about } \\
\text { the reusability of this type of RAMIP. Two } \\
\text { papers related that the material could be } \\
\text { used in various extraction cycles ( } 5 \text { and } \\
90 \text { ), and the other one reported that the } \\
\text { RAMIP was not reusable, being used just } \\
\text { one time. }\end{array}$ \\
\hline
\end{tabular}

* Not all the papers used in this review reported if the material was reusable or not as well as already presented in Table I.

BSA: bovine serum albumin. 


\section{CONCLUSIONS}

RAMIPs are a suitable alternative to complex sample preparation procedures, because of their high selective, ability to exclude proteins and resistant to high temperatures, $\mathrm{pHs}$, and solvents. According to the papers presented in this review, the average of proteins exclusion percentages for each strategy were $89.60 \%(53.3-100 \%), 94.75 \%(87.3-99 \%)$ and $99.48 \%(98.7-100 \%)$ to MIPs surface modified with hydrophilic comonomers, bovine serum albumin and both, respectively. These results corroborate with the study of Santos et al [14], in which the MIPs covering with double layer (hydrophilic monomers + BSA) are better in terms of protein exclusion. Additionally, the BSA-based RAMIPs are promising as materials for biomedical applications, due to their biocompatibility and low inability to generate immune response. However, the presence of BSA layer can result in loss of selectivity, probably due to the obstruction of selective binding sites, as well as by unselective binding of molecules in the BSA structure.

Owing to these results, all the demonstrated strategies to convert MIPs into RAMIPs result in selectively materials able to exclude macromolecules from untreaded complex samples. Moreover, RAMIPs are promising materials to be used in different sample preparation techniques, sensors, proteins depletion systems, and routine analyses, and commercial materials such as columns and fibers can be available in the future.

\section{Conflicts of interest}

Authors declare that there is no conflict of interest.

\section{Acknowledgements}

The authors are thankful to the Fundação de Amparo à Pesquisa do Estado de Minas Gerais (FAPEMIG, Belo Horizonte, MG, Brazil) [project CDS-APQ-00638-17]; the Conselho Nacional de Desenvolvimento Científico e Tecnológico (CNPq, Brasília, DF, Brazil) [project 301564/2019-1, 427365/2018-0]; and the Coordenação de Aperfeiçoamento de Pessoal de Nível Superior (CAPES) for financial support. The authors are also thankful to Royal Society of Chemistry for permission to reprint Figure 6.

\section{REFERENCES}

1. Nazario, C. E. D.; Fumes, B. H.; da Silva, M. R.; Lanças, F. M. J. Chromatogr. B, 2017, 1043, pp 81-95 (https://doi.org/10.1016/j.jchromb.2016.10.041).

2. Kubo, T.; Otsuka, K. Molecularly Imprinted Materials. In: de La Guardia, M.; Esteves-Turrillas, F. A. (Ed.). Handbook of Smart Materials in Analytical Chemistry. John Wiley \& Sons, Chichester, UK, 2019, pp 159-178.

3. De Faria, H. D.; Abrão, L. C. C.; Santos, M. G.; Barbosa, A. F.; Figueiredo, E. C. Anal. Chim. Acta, 2017, 959, pp 43-65 (https://doi.org/10.1016/j.aca.2016.12.047).

4. Sellergren, B. Anal. Chem., 1994, 66 (9), pp 1578-1582 (https://doi.org/10.1021/ac00081a036).

5. He, J.; Song, L.; Chen, S.; Li, Y.; Wei, H.; Zhao, D., Gu, K.; Zhang, S. Food Chem., 2015, 187, pp 331-337 (https://doi.org/10.1016/j.foodchem.2015.04.069).

6. Majors, R. E. LC-GC, 1991, 9, pp 16-20.

7. Haginaka, J.; Takehira, H.; Hosoya, K.; Tanaka, N. J. Chromatogr. A, 1999, 849 (2), pp 331-339 (https:// doi.org/10.1016/S0021-9673(99)00570-1).

8. Xu, W.; Su, S.; Jiang, P.; Wang, H.; Dong, X.; Zhang, M. J. Chromatogr. A, 2010, 1217 (46), pp 71987207 (https://doi.org/10.1016/j.chroma.2010.09.035).

9. Li, X.; Zhou, M., Turson, M.; Lin, S.; Jiang, P.; Dong, X. Analyst, 2013, 138 (10), pp 3066-3074 (https:// doi.org/10.1039/c3an36801g).

10. Souverain, S.; Rudaz, S.; Veuthey, J. L. J. Chromatogr. B, 2004, 801 (2), pp 141-156 (https://doi. org/10.1016/j.jchromb.2003.11.043).

11. Mullett, W. M. J. Biochem. Biophys. Methods, 2007, 70 (2), pp 263-273 (https://doi.org/10.1016/j. jbbm.2006.10.001).

12. Haginaka, J.; Sanbe, H. Anal. Chem., 2000, 72 (21), pp 5206-5210 (https://doi.org/10.1021/ac0005215). 
13. Santos, M. G.; Tavares, I. M. C.; Barbosa, A. F.; Bettini, J.; Figueiredo, E. C. Talanta, 2017, 163, pp 8-16 (https://doi.org/10.1016/j.talanta.2016.10.047).

14. Maciel, E. V. S.; de Toffoli, A. L.; Neto, E. S.; Nazario, C. E. D.; Lanças, F. M. TrAC, Trends Anal. Chem., 2019, 119, 115633 (https://doi.org/10.1016/j.trac.2019.115633).

15. Gama, M. R.; Bottoli, C. B. G. J. Chromatogr. B, 2017, 1043, pp 107-121 (https://doi.org/10.1016/j. jchromb.2016.09.045).

16. Speltini, A.; Scalabrini, A.; Maraschi, F.; Sturini, M.; Profumo, A. Anal. Chim. Acta, 2017, 974, pp 1-26 (https://doi.org/10.1016/j.aca.2017.04.042).

17. Fumes, B. H.; Silva, M. R.; Andrade, F. N.; Nazario, C. E. D.; Lanças, F. M. TrAC, Trends Anal. Chem., 2015, 71, pp 9-25 (https://doi.org/10.1016/j.trac.2015.04.011).

18. Szatkowska, P.; Koba, M.; Koslinski, P.; Szablewski, M. Mini-Rev. Org. Chem., 2013, 10 (4), pp 400408 (https://doi.org/10.2174/1570193X11310030016).

19. Płotka-Wasylka, J.; Szczepańska, N.; de la Guardia, M.; Namieśnik, J. TrAC, Trends Anal. Chem., 2016, 77, pp 23-43 (https://doi.org/10.1016/j.trac.2015.10.010).

20. Hu, T.; Chen, R.; Wang, Q.; He, C.; Liu, S. J. Sep. Sci., 2021, 44 (1), pp 274-309 (https://doi.org/10.1002/ jssc. 202000832).

21. Faraji, M.; Yamini, Y.; Gholami, M. Chromatographia, 2019, 82 (8), pp 1207-1249 (https://doi. org/10.1007/s10337-019-03726-9).

22. Kubo, T.; Otsuka, K. J. Pharm. Biomed. Anal., 2016, 130, pp 68-80 (https://doi.org/10.1016/j. jpba.2016.05.044).

23. Arabi, M.; Ostovan, A.; Bagheri, A. R.; Guo, X.; Wang, L.; Li, J.; Wang, X.; Li, B.; Chen, L. TrAC, Trends Anal. Chem., 2020, 128, 115923 (https://doi.org/10.1016/j.trac.2020.115923).

24. Cruz, J. C.; de Souza, I. D.; Grecc, C. F.; Figueiredo, E. C.; Queiroz, M. E. C. Sustainable Chem. Pharm., 2021, 21 (April), 100431 (https://doi.org/10.1016/j.scp.2021.100431).

25. Kataoka, H.; Ishizaki, A.; Nonaka, Y.; Saito K. Anal. Chim. Acta, 2009, 655 (1-2), pp 8-29 (https://doi. org/10.1016/j.aca.2009.09.032).

26. Xu, L.; Hu, Z. S.; Duan, R.; Wang, X.; Yang, Y. S.; Dong, L. Y.; Wang, X. H. J. Chromatogr. A, 2021, 1640, 461962 (https://doi.org/10.1016/j.chroma.2021.461962).

27. Zhou, T.; Ding, L.; Che, G.; Jiang, W.; Sang, L. TrAC, Trends Anal. Chem., 2019, 114, pp 11-28 (https:// doi.org/10.1016/j.trac.2019.02.028).

28. Wang, H.; Jiang, P.; Zhang, M.; Dong, X. J. Chromatogr. A, 2011, 1218 (9), pp 1310-1313 (https://doi. org/10.1016/j.chroma.2011.01.005).

29. Nimura, N.; Itoh, H.; Kinoshita, T. J. Chromatogr. A, 1995, 689 (2), pp 203-210 (https://doi. org/10.1016/0021-9673(94)00896-H).

30. Elbert, D. L.; Hubbell, J. A. Annu. Rev. Mater. Sci., 1996, 26 (1), pp 365-394 (https://doi.org/10.1146/ annurev.ms.26.080196.002053).

31. Wang, Y. X.; Robertson, J. L.; Spillman Jr., W. B.; Claus, R. O. Pharm. Res., 2004, 21 (8), pp 13621373 (https://doi.org/10.1023/B:PHAM.0000036909.41843.18).

32. Liu, K.; Tian, Y.; Jiang, L. Prog. Mater. Sci., 2013, 58 (4), pp 503-564 (https://doi.org/10.1016/j. pmatsci.2012.11.001).

33. de Oliveira, H. L.; Pires, B. C.; Teixeira, L. S.; Dinali, L. A. F.; do Nascimento, T. A.; Borges, K. B. Colloids Surfaces A Physicochem. Eng. Asp., 2020, 590, 124506 (https://doi.org/10.1016/j. colsurfa.2020.124506).

34. Liu, H.; Ding, J.; Zhang, K.; Ding, L. Talanta, 2020, 209, 120508 (https://doi.org/10.1016/j. talanta.2019.120508).

35. Liang, T.; Chen, L.; Ma, Y. J. Chromatogr. A, 2020, 1609, 460453 (https://doi.org/10.1016/j. chroma.2019.460453).

36. de Oliveira, H. L.; Pires, B. C.; Teixeira, L. S.; Dinali, L. A. F.; Simões, N. S.; Borges, W. S.; Borges, K. B. Microchem. J., 2019, 149, 104043 (https://doi.org/10.1016/j.microc.2019.104043). 
37. Zhou, Y.; Liu, H.; Li, J.; Sun, Z.; Cai, T.; Wang, X.; Zhao, S.; Gong, B. J. Chromatogr. A, 2020, 1613, 460684 (https://doi.org/10.1016/j.chroma.2019.460684).

38. de Oliveira, H. L.; Teixeira, L. S.; Dinali, L. A. F.; Pires, B. C.; Simões, N. S.; Borges, K. B. Microchem. J., 2019, 150, 104162 (https://doi.org/10.1016/j.microc.2019.104162).

39. Sanbe, H.; Haginaka, J. Analyst, 2003, 128 (6), pp 593-597 (https://doi.org/10.1039/b301257n).

40. Santos, M. G.; Tavares, I. M. C.; Boralli, V. B.; Figueiredo, E. C. Analyst, 2015, 140 (8), pp 2696-2703 (https://doi.org/10.1039/c4an02066a).

41. Souza, I. D.; Melo, L. P.; Jardim, I. C. S. F.; Monteiro, J. C. S.; Nakano, A. M. S.; Queiroz, M. E. C. Anal. Chim. Acta, 2016, 932, pp 49-59 (https://doi.org/10.1016/j.aca.2016.05.027).

42. Manouchehri, M.; Seidi, S.; Rouhollahi, A.; Noormohammadi, H., Shanehsaz, M. Food Chem., 2020, 314, 126223 (https://doi.org/10.1016/j.foodchem.2020.126223).

43. Grecco, C.; Souza, I.; Acquaro Junior, V. R.; Queiroz, M. E. C. J. Braz. Chem. Soc., 2018, 30 (1), pp 48-59 (https://doi.org/10.21577/0103-5053.20180151).

44. Ma, Y.; Pan, G.; Zhang, Y.; Guo, X.; Zhang, H. Angew. Chem., Int. Ed. Engl., 2013, 52 (5), pp 15111514 (https://doi.org/10.1002/anie.201206514).

45. Li, X.; Zhang, B.; Tian, L.; Li, W.; Zhang, H.; Zhang, Q. Sens. Actuators, B, 2015, 208, pp 559-568 (https://doi.org/10.1016/j.snb.2014.11.045).

46. Puoci, F.; lemma, F.; Cirillo, G.; Curcio, M.; Parisi, O. I.; Spizzirri, U. G.; Picci, N. Eur. Polym. J., 2009, 45 (6), pp 1634-1640 (https://doi.org/10.1016/j.eurpolymj.2009.01.021).

47. Wang, X.; Zhao, L.; Sun, Z.; Gong, B. Chromatographia, 2019, 82 (7), pp 1041-1050 (https://doi. org/10.1007/s10337-019-03738-5).

48. Du, B.; Qu, T.; Chen, Z.; Cao, X.; Han, S.; Shen, G.; Wang, L. Talanta, 2014, 129, pp 465-472 (https:// doi.org/10.1016/j.talanta.2014.05.005).

49. Zhao, S.; Wei, C.; Sun, Z.; Liu, H.; Zhou, Y.; Wang, X.; Li, J.; Gong, B. J. Anal. Methods Chem., 2019, 2019, pp 1-12 (https://doi.org/10.1155/2019/7930102).

50. Zuo, H. G.; Yang, H.; Zhu, J. X.; Ding, Y. Anal. Methods, 2017, 9 (42), pp 6009-6018 (https://doi. org/10.1039/C7AY01941F).

51. de Oliveira, F. M.; Segatelli, M. G.; Tarley, C. R. T. J. Appl. Polym. Sci., 2016, 133 (21) (https://doi. org/10.1002/app.43463).

52. Oliveira, F. M.; Segatelli, M. G.; Tarley, C. R. T. Anal. Methods, 2016, 8 (3), pp 656-665 (https://doi. org/10.1039/C5AY02410B).

53. Niu, Y.; Liu, C.; Yang, J.; Ma, M.; Gong, Y.; Wang, Y.; Gong, B. Food Anal. Methods, 2016, 9 (8), pp 2342-2351 (https://doi.org/10.1007/s12161-016-0422-9).

54. Zuo, H.; Lin, Y.; Ma, X.; Feng, Y.; Luo, Q. Soil and Sediment Contamination: An International Journal, 2019, 28 (6), pp 529-546 (https://doi.org/10.1080/15320383.2019.1633272).

55. Abrão, L. C. C.; Maia, P. P.; Figuereido, E. C. Anal. Lett., 2014, 47, pp 2183-2194 (https://doi.org/10.1 080/00032719.2014.900780).

56. de Oliveira, I. M. G.; da Silva, L. M. R.; dos Santos-Neto, Á. J.; Florenzano, F. H.; Figueiredo, E. C. Anal. Bioanal. Chem., 2013, 405 (24), pp 7687-7696 (https://doi.org/10.1007/s00216-013-7275-5).

57. Gomes, R. A. B.; Luccas, P. O.; de Magalhães, C. S.; Figueiredo E. C. J. Mater. Sci., 2016, 51 (16), pp 7407-7414 (https://doi.org/10.1007/s10853-016-9984-6).

58. Mendes, T. V.; Franqui, L. S.; Santos, M. G; Wisniewski, C.; Figueiredo, E. C. Mater. Today Commun., 2020, 24, 101002 (https://doi.org/10.1016/j.mtcomm.2020.101002).

59. Santos, M. G.; Moraes, G. D. O. I.; Nakamura, M. G.; dos Santos-Neto, Á. J.; Figueiredo, E. C. Analyst, 2015, 140 (22), pp 7768-7775 (https://doi.org/10.1039/C5AN01482D).

60. da Silva, K. K. M. S.; Boralli, V. B.; Wisniewski, C.; Figueiredo, E. C. J. Anal. Toxicol., 2016, 40 (2), pp 108-116 (https://doi.org/10.1093/jat/bkv121).

61. de Lima, M. M.; Vieira, A. C.; Martins, I.; Boralli, V. B.; Borges, K. B.; Figueiredo, E. C. Food Chem., 2016, 197, pp 7-13 (https://doi.org/10.1016/j.foodchem.2015.10.082). 
62. Sun, Z.; Liu, H.; Zhou, Y.; Zhao, S.; Li, J.; Wang, X.; Gong, B. RSC Adv., 2019, 9 (48), pp 27953-27960 (https://doi.org/10.1039/C9RA04143E).

63. da Silveira, J. P.; Piovesan, J. V.; Spinelli, A. Microchem. J., 2017, 133, pp 22-30 (https://doi. org/10.1016/j.microc.2017.03.010).

64. Liao, K.; Mei, M.; Li, H.; Huang, X.; Wu, C. J. Sep. Sci., 2016, 39 (3), pp 566-575 (https://doi.org/10.1002/ jssc.201501156).

65. Abrão, L. C. D. C.; Figueiredo, E. C. Analyst, 2019, 144 (14), pp 4320-4330 (https://doi.org/10.1039/ C9AN00444K).

66. Wang, D. D.; Gao, D.; Huang, Y. K.; Xu, W. J.; Xia, Z. N. Talanta, 2019, 202, pp 392-401 (https://doi. org/10.1016/j.talanta.2019.05.016).

67. Rosa, M. A.; De Faria, H. D.; Carvalho, D. T.; Figueiredo, E. C. Microchim. Acta, 2019, 186 (9), p 647 (https://doi.org/10.1007/s00604-019-3774-1).

68. Hua, K.; Zhang, L.; Zhang, Z.; Guo, Y.; Guo, T. Acta Biomater., 2011, 7 (8), pp 3086-3093 (https://doi. org/10.1016/j.actbio.2011.05.006).

69. Parisi, O. I.; Cirillo, G.; Curcio, M.; Puoci, F.; Iemma, F.; Spizzirri, U. G.; Picci, N. J. Polym. Res., 2010, 17 (3), pp 355-362 (https://doi.org/10.1007/s10965-009-9322-7). 